\title{
Strengthening of self-compacting reinforced concrete deep beams containing circular openings with CFRP
}

\author{
Nabeel Al-Bayati, ${ }^{1, *}$, Bassman Muhammad ${ }^{1}$, and Murooj Faek $^{1}$ \\ ${ }^{1}$ Building and Construction Engineering Department, University of Technology, Baghdad, Iraq
}

\begin{abstract}
This paper shows the behavior of reinforced self-compacting concrete deep beams with circular openings strengthened in shear with various arrangements of externally bonded Carbon Fibre Reinforced Polymer (CFRP). Six simply supported deep beams were constructed and tested under two points load up to the failure for this purpose. All tested beams had same geometry, compressive strength, shear span to depth ratio, main flexural and web reinforcement. The variables considered in this study include the influence of fiber orientation, utilizing longitudinal CFRP strips with vertical strips and area of CFRP. The test results indicated that the presence of the circular openings in center of load path reduce stiffness and ultimate strength by about $50 \%$ when compared with solid one, also it was found that the externally bonded CFRP can significantly increase the ultimate load and enhance the stiffness of deep beam with openings.
\end{abstract}

\section{Introduction}

Deep beams are significant structural elements in which most of the applied load transferred directly to supports by tied arch[1] they are used as transfer girder in bridges and buildings, panel beams, foundation walls of rectangular tanks, walls of bunker, load bearing walls in buildings, and pile cap. Because of the deep beam commonly has a small width, big depth and contain heavy web reinforcement, therefore; the use of self-compacting concrete (SCC) for casting of those members more convenient to avoid the usual problems of utilization conventional concrete such as segregation, voids and bleeding. This type of concrete is different from conventional concrete by its ability to spread readily under self-weight only and fill the formwork without need any mechanical compaction compaction [2]. In many cases, transverse openings in such member are often provided for the passage of utility ducts and drainage pipes. These openings cause many problems in behavior of the deep beams particularly when these openings were located to interrupt the load path which define as (the line joining the load bearing edge and support bearing edge)[3-6] as a result of reduction in beam stiffness such as increased cracking and deflection and may be a reduction in beams carrying capacity. Deep beams like other structural members needed strengthening or rehabilitation programs due to extra load or mistake in their design or construction without rise their self-weight. The use of externally bonded Carbon Fiber-Reinforced Polymer (CFRP) for the strengthening of Reinforced Concrete structure (RC) is becoming very common in recent years. Because of their higher strength to corrosion, higher strength to weight ratio, comfort of handling and application, has higher strength and stiffness compared to steel and availability in various lengths and shapes.

\section{Research significance}

No enough research was found deals with the strengthening self-compacting deep beams containing circular openings positioned to interrupt the load path with CFRP fabric. So this paper is prepared to provide experimental information about the shear strength and behavior of this type of structural members strengthening with different configuration of CFRP.

\section{Experimental program}

A total of six self-compacting concrete (SCC) deep beams were constructed and tested under two points loading applied on the top face. All specimens had total long $1400 \mathrm{~mm}$ and cross section of $150 \times 400 \mathrm{~mm}$, shear span to depth ratio $(\mathrm{a} / \mathrm{d})$ equal to $(1)$, the clear span between the simply support $1070 \mathrm{~mm}$ which give L/D ratio equal 2.67 less than 4 as recommended in ACI $318 \mathrm{M}$ 14[7] for deep beam requirements, Details of the flexure and shear reinforcement in both vertical and horizontal directions shown in Figure. (1). Two circular openings with diameter $110 \mathrm{~mm}$ were placed in the center of load path in two sides of the beam in five specimens and one solid beam as the reference beam. Four specimens from

"Corresponding author: 40063@,votechnology.edu.ig 
deep beams with openings strengthened in the shear zone with uni-directional CFRP strips of $40 \mathrm{~mm}$ wide with different configuration and one specimen unstrengthened were served as the reference beam. Details of the beams are mentioned in Table (1) and Figure (2). The beam notation contained three parts; in the first part the letter (D) refers to deep beam, (O) refers to presence the circular openings, the second part indicates to the shear span to effective depth ratio; and the third part indicates to the type of strengthening. As an example, DO-1-V refers to a deep beam with openings, a/d equals to 1 , type of strengthening was vertical strips.

\section{Material properties}

\subsection{Cement}

An Ordinary Portland cement (type I) made in a MassBazian Factory, Sulymania- Iraq, was used in this work. The physical and chemical properties of this cement are corresponding to the requirements of the Iraqi standard specifications IQS NO.5/1984[8] as shown in Table 2 and 3.

\subsection{Fine sand}

Natural sand from Al-akhaidur region was used for this study. It has a fineness modulus of 2.55. The grading and sulfate content of this sand were conformed with the requirement of specification ASTM C33-03[9] and IQS No.45/1984[10] as shown in Table 4 and 5

\subsection{Coarse aggregate}

Crushed river gravel brought from Al-Niba'ee region has $(14 \mathrm{~mm})$ maximum size was utilized in this work. The physical and chemical properties and grading of it complies with the Iraqi specification IQS No.45/1984[10] as shown in Table 6 and 7.

\subsection{Limestone powder (LSP)}

This material is commercially known as "Al-Ghubra". Fine limestone was utilized as a filler to increase the amount of fine materials in this mixture to improve segregation resistance and enhance its cohesiveness. Chemical composition of limestone powder shown in Table 8 .

\subsection{Superplasticize}

Aqueous solution of modified polycarboxylate commercially named as Sika viscocrete was used to obtain fresh properties of SCC. All information about main properties of this material is summarized in Table 9.

\subsection{Steel reinforcement}

Three deformed steel bars were utilized with a diameter of $16 \mathrm{~mm}$ as the flexural reinforcement and shear reinforcement made with $5 \mathrm{~mm}$ diameter deformed steel wires spaced at $75 \mathrm{~mm} \mathrm{C} / \mathrm{C}$. Test results indicated that the steel reinforcement of $\varnothing 16$ conforms to the requirements of the ASTM A615/615M-14[11] for grade 60 bars of minimum yield stress $=420 \mathrm{MPa}$ and elongation $=9 \%$. Furthermore, the deformed wire reinforcement $\varnothing 5$ complies with the requirements of the ASTM A1064/A1064M-14[12] which recommended minimum values for yield stress and ultimate stress of 515 and 585 $\mathrm{MPa}$, as shown in Table10.

\subsection{Carbon fiber reinforced polymer (CFRP)}

Unidirectional woven carbon fiber fabric known as Sika Wrap-300 C/60 was used for externally strengthening in this study. All information about main properties of this material is summarized in Table 11.

\subsection{Bonding materials}

Sikadur ${ }^{\circledR}-330$ is the suitable adhesive material for carbon fiber fabric strips comprises of two parts, white part (resin) called part A, and grey part (hardener) called part B. The properties of this type of adhesive are mentioned in Table 12.

\section{Mixing, casting and curing of con- crete specimens}

The mix design of Self-Compacting Concrete must achieve the criteria of filling ability and segregation resistance. In the present work the SCC mix was designed according to requirements of European Guidelines for Self-Compacting Concrete [13] to a ccomplish both fresh and hardened properties of SCC. Many trail mixes were made to achieve a minimum compressive strength of $32 \mathrm{MPa}$ at 28 days and to ensure the SCC requirements slump flow, T50, L-box V-Funnel tests carried out. Tables 13 and 14 indicate the details of 


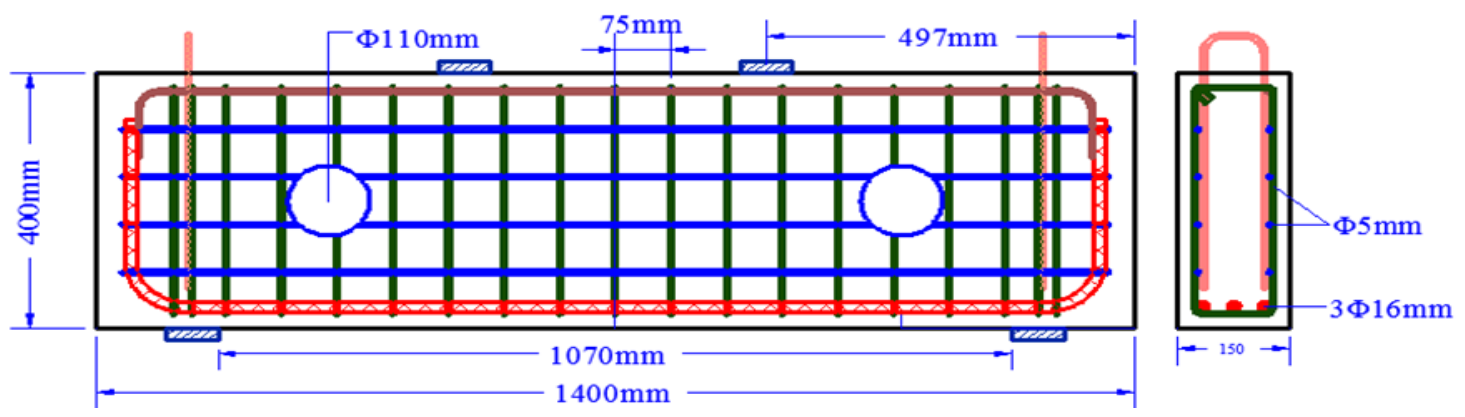

Fig. 1. Reinforced concrete deep beam
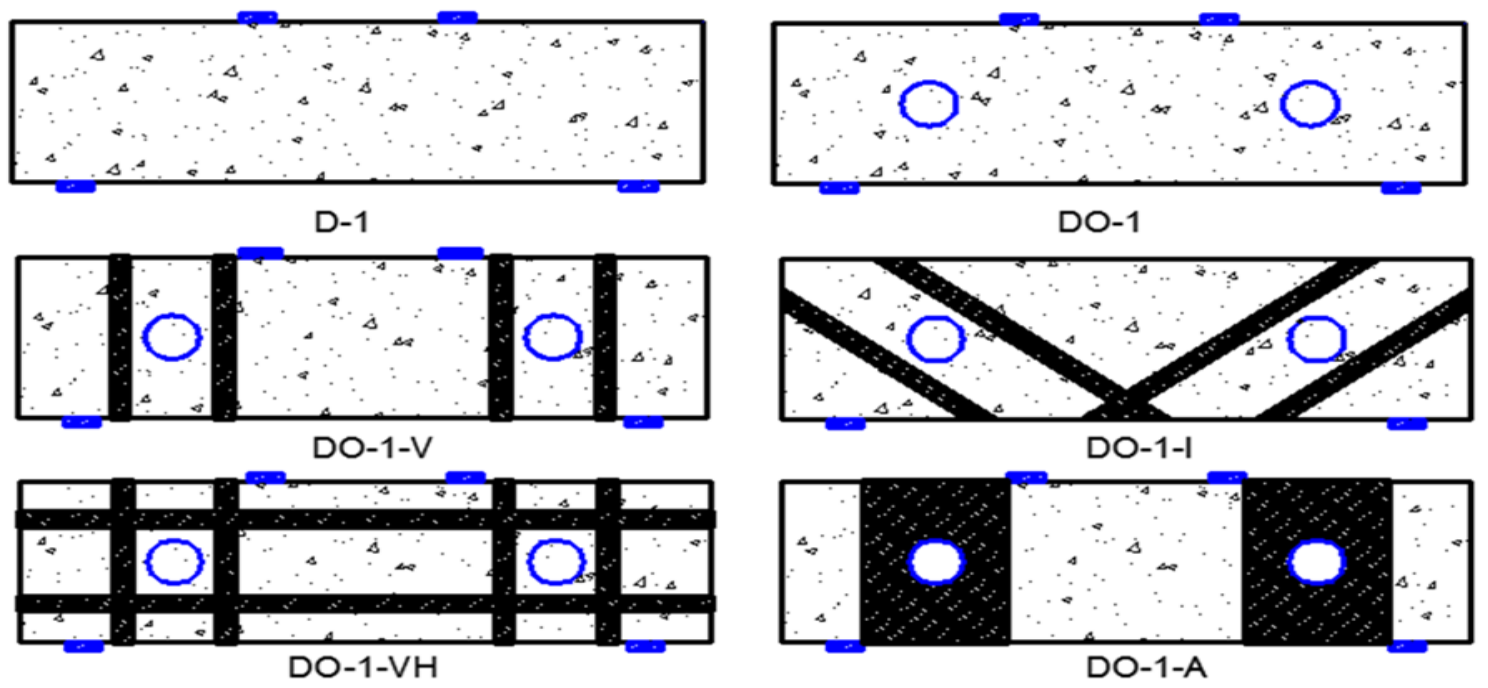

Fig. (2) Strengthening Schemes of the Tested Deep Beams

Table 1. Summary of specimens Details

\begin{tabular}{|c|c|c|c|c|}
\hline No & $\begin{array}{c}\text { Specimen } \\
\text { Symbols }\end{array}$ & $\begin{array}{c}\text { Openings } \\
\text { diameter(mm) }\end{array}$ & a/d & Strengthening details \\
\hline $\begin{array}{c}1 \text { Solid } \\
\text { beam }\end{array}$ & D-1 & - & 1 & No strengthening \\
\hline 2 & DO-1 & 110 & 1 & No strengthening \\
\hline 3 & DO-1-V & 110 & 1 & Two vertical U-shape strips \\
\hline 4 & DO-1-VH & 110 & 1 & $\begin{array}{c}\text { Two vertical U-shape strips at two sides of beam and } \\
\text { two horizontal strips at two faces of beam }\end{array}$ \\
\hline 5 & DO-1-I & 110 & 1 & Two inclined U-shape strips \\
\hline 6 & DO-1-A & 110 & 1 & Covering all shear span with vertical U-shape fiber \\
\hline
\end{tabular}

Table 2. Physical properties of the cement

\begin{tabular}{|c|c|c|c|}
\hline Physical Properties & Unit & Test results & IQS 5/1984 \\
\hline $\begin{array}{c}\text { Fineness uses Blaine air permeability appa- } \\
\text { ratus }\end{array}$ & $\mathrm{m}^{2} / \mathrm{Kg}$ & 380 & $230 \mathrm{~min}$ \\
\hline Soundness using autoclave method & $\%$ & 0.24 & $0.8 \mathrm{max}$ \\
\hline $\begin{array}{c}\text { Time of setting (Vicat) } \\
\text { Initial time } \\
\text { Final time }\end{array}$ & $\begin{array}{c}\text { minutes } \\
\text { minutes }\end{array}$ & 158 & $45 \mathrm{~min}$ \\
273 & $600 \mathrm{max}$ \\
\hline $\begin{array}{c}\text { Compressive strength of cement paste cube } \\
\text { mold (50mm) at: }\end{array}$ & $\mathrm{MPa}$ & 29.52 & $15 \mathrm{~min}$ \\
3days & $\mathrm{MPa}$ & 34 & $23 \mathrm{~min}$ \\
7days & & & \\
\hline
\end{tabular}


Table 3. Chemical properties of cement

\begin{tabular}{|c|c|c|c|c|}
\hline No. & Compound name & Chemical composition & \% by Weight & IQS 5/1984 \\
\hline 1 & Lime & $\mathrm{CaO}$ & 61 & - \\
\hline 2 & Silica & $\mathrm{SiO}_{2}$ & 21.1 & - \\
\hline 3 & Alumina & $\mathrm{AI}_{2} \mathrm{O}_{3}$ & 4.64 & - \\
\hline 4 & Iron oxide & $\mathrm{Fe}_{2} \mathrm{O}_{3}$ & 4.2 & - \\
\hline 5 & Magnesium oxide & $\mathrm{MgO}$ & 1.51 & $2.8 \max$ \\
\hline 6 & Sulfur trioxide & $\mathrm{SO}_{3}$ & 2.35 & $4 \max$ \\
\hline 7 & Loss on ignition & $\mathrm{L} . \mathrm{O} . \mathrm{I}$ & 2.79 & 0.81 \\
\hline 8 & Insoluble residue & $\mathrm{I} . \mathrm{R}$ & 0.88 & - \\
\hline 9 & Lime saturation factor & $\mathrm{L} . \mathrm{S} . \mathrm{F}$ & 5.2 & - \\
\hline 10 & Tricalcium aluminates & $\mathrm{C}_{3} \mathrm{~A}$ & 44 & - \\
\hline 11 & Tricalcium silicate & $\mathrm{C}_{3} \mathrm{~S}$ & 27.39 & - \\
\hline 12 & Dicalcium silicate & $\mathrm{C}_{2} \mathrm{~S}$ & 12.8 & - \\
\hline 13 & Tetracalcium & $\mathrm{C}_{4} \mathrm{AF}$ & & \\
\hline
\end{tabular}

Table 4. Physical properties of fine aggregate

\begin{tabular}{|c|c|c|}
\hline Physical Properties & Test Results & Limits of Iraqi Standard IQS.No.45, 1984 \\
\hline Specific Gravity & 2.59 & - \\
\hline Sulfate Content $\%$ & 0.12 & $\leq 0.5$ \\
\hline Absorption $\%$ & 0.75 & - \\
\hline
\end{tabular}

Table 5. Grading of fine aggregate

\begin{tabular}{|c|c|c|}
\hline Sieve size $(\mathrm{mm})$ & \% Passing by Weight & IQS45/1984 for zone 2 \\
\hline 10 & 100 & 100 \\
\hline 4.75 & 100 & $90-100$ \\
\hline 2.36 & 88 & $75-100$ \\
\hline 1.18 & 76.9 & $55-90$ \\
\hline 0.6 & 57.9 & $35-59$ \\
\hline 0.3 & 20 & $8-30$ \\
\hline 0.15 & 2 & $0-10$ \\
\hline
\end{tabular}

Table 6. Physical properties and sulfate content of coarse aggregate

\begin{tabular}{|c|c|c|}
\hline Properties & \%Passing by weight & IQ45/1984 for zone 2 \\
\hline Specific gravity & 2.63 & - \\
\hline SO3 \% & 0.07 & $0.1 \max$ \\
\hline Absorption \% & 0.8 & - \\
\hline
\end{tabular}

Table 7. Grading of coarse aggregate

\begin{tabular}{|c|c|c|}
\hline Sive size $(\mathrm{mm})$ & \% Passing by weight & IQS45/1984 \\
\hline 14 & 100 & $90-100$ \\
\hline 10 & 80 & $50-85$ \\
\hline 5 & 5 & $0-10$ \\
\hline
\end{tabular}


Table 8. Chemical Composition of Limestone Powder

\begin{tabular}{|c|c|}
\hline Oxide Composition & Content by weight \% \\
\hline $\mathrm{CaO}$ & 54.1 \\
\hline $\mathrm{MgO}$ & 0.12 \\
\hline $\mathrm{SiO}_{2}$ & 1.4 \\
\hline $\mathrm{Fe}_{2} \mathrm{O}_{3}$ & 0.13 \\
\hline $\mathrm{Al}_{2} \mathrm{O}_{3}$ & 0.7 \\
\hline $\mathrm{SO}_{3}$ & 0.21 \\
\hline Loss on ignition & 42.57 \\
\hline
\end{tabular}

Table 9. Properties of Superplasticizer

\begin{tabular}{|c|c|}
\hline From & liquid \\
\hline Color & Turbid liquid \\
\hline Specific Gravity & $1.08 \mathrm{Kg} / 1$ \\
\hline $\mathrm{pH}$ & $7.0-9.0$ \\
\hline Normal dosage & $0.8-2 \%$ \\
\hline Chorides & Free from choride \\
\hline Transport & Non-hazardous \\
\hline Labeling & No hazard label required \\
\hline
\end{tabular}

Table 10. Properties of steel bars

\begin{tabular}{|c|c|c|c|}
\hline Bar Diameter $(\mathrm{mm})$ & Yield Stress $(\mathrm{MPa})$ & Ultimate stress $(\mathrm{MPa})$ & Elongation \% \\
\hline 16 & 590 & 692 & 15.16 \\
\hline 5 & 554 & 617 & 5 \\
\hline
\end{tabular}


Table 11. Properties of CFRP

\begin{tabular}{|c|c|}
\hline Properties & Sika Warp 300c/60 \\
\hline Tensile strength $(\mathrm{MPa})$ & 3900 \\
\hline Density $(\mathrm{g} / \mathrm{cm} 2)$ & 1.79 \\
\hline Elongation at break\% & 1.5 \\
\hline Tensile modulus $(\mathrm{MPa})$ & 230000 \\
\hline Weight $(\mathrm{g} / \mathrm{m} 2)$ & 300 \\
\hline Thickness $(\mathrm{mm})$ & 0.166 \\
\hline
\end{tabular}

Table 12. Properties of Epoxy Resin

\begin{tabular}{|c|c|}
\hline Properties & Sikadur-330 \\
\hline Density (kg/l) & Mixed Res-in:1.31 \\
\hline Mixing ratio by weight A:B & $4: 1$ \\
\hline Tensile strength (MPa) & 30 \\
\hline Flexural modulus (MPa) & 3800 \\
\hline Elongation at break(\%) & 0.9 \\
\hline Setting time (minute) & 30 \\
\hline Full cure (day) & 7 \\
\hline
\end{tabular}

Table 13. SCC mix proportion by weight

\begin{tabular}{|c|c|}
\hline Super plasticizer $\left(\mathrm{L} / \mathrm{m}^{3}\right)$ & 4.9 \\
\hline Fine aggregate $\left(\mathrm{Kg} / \mathrm{m}^{3}\right)$ & 797 \\
\hline Coars aggregate $\left(\mathrm{Kg} / \mathrm{m}^{3}\right)$ & 767 \\
\hline Water/ Powder $(\mathrm{by}$ Weight $)$ & 0.34 \\
\hline Water $\left(\mathrm{Kg} / \mathrm{m}^{3}\right)$ & 180 \\
\hline Limestone powder $\left(\mathrm{Kg} / \mathrm{m}^{3}\right)$ & 175 \\
\hline
\end{tabular}

\begin{tabular}{|l|l|}
\hline Cement $\left(\mathrm{Kg} / \mathrm{m}^{3}\right)$ & 350 \\
\hline
\end{tabular}

Table 14. Fresh SCC test results

\begin{tabular}{|c|c|c|c|}
\hline Test method & Results & $\begin{array}{c}\text { EFNARC (2002) } \\
\text { Limits[14] }\end{array}$ & $\begin{array}{c}\text { ACI237R-07 } \\
\text { Limits[2] }\end{array}$ \\
\hline $\begin{array}{c}\text { Slump flow } \\
(\mathrm{mm})\end{array}$ & 710 & $650-800$ & $450-760$ \\
\hline T500(Sec) & 3 & $2-5$ & $2-5$ \\
\hline L-box (H2/H1) & 0.9 & $0.8-1$ & $0.8-1$ \\
\hline V-Funnel (Sec) & 10 & $6-12$ & - \\
\hline
\end{tabular}

the adopted SCC mixture and test results respectively. Furthermore concrete compressive strength $\left(f^{\prime} c\right)$ and splitting tensile strength $(f c t)$ was determined by testing three $150 \times 300 \mathrm{~mm}$ cylinders, also modulus of rupture ( $f r)$ was determined utilizing three $100 \times 100 \times 400 \mathrm{~mm}$ prisms. The test results are shown in Table 15 .

Table 15. Test results of hardened SCC

\begin{tabular}{|c|c|c|c|}
\hline Beams & $\begin{array}{c}\text { D-1 } \\
\text { DO-1 }\end{array}$ & $\begin{array}{c}\text { DO-1-V } \\
\text { DO-1-VH }\end{array}$ & $\begin{array}{c}\text { DO-1-I } \\
\text { DO-1-A }\end{array}$ \\
\hline$f^{\prime}{ }_{c}(\mathrm{MPa})$ & 34.14 & 33.5 & 34.3 \\
\hline$f_{c t}(\mathrm{MPa})$ & 3 & 3.38 & 3.35 \\
\hline$f r(\mathrm{MPa})$ & 4.5 & 4.42 & 6.2 \\
\hline
\end{tabular}

Each beam was cast utilizing two batches of SCC mix in vertically positioned steel formworks then cured for 28 days utilizing wet burlaps after removing the formwork. Four deep beams with openings were strengthened by one layer, U-shaped of CFRP strips that have constant width $(40 \mathrm{~mm})$. The locations of CFRP strips were chosen carefully based on the failure mode of the reference beams. The strengthening schemes of specimens are described in detail in Table 1 and Figure 2.

\section{Devices and testing procedure}

The specimens were tested utilizing the universal testing machine (AVERY) of $3000 \mathrm{kN}$ capacity at the Structural Laboratory of Building and Construction Department of the University of Technology/ Baghdad /Iraq. Loading was applied in small increase $(20 \mathrm{kN})$. At each load level, midspan deflection was recorded utilizing dial gage of accuracy of $0.01 \mathrm{~mm}$. The first cracking load was noted, and the crack patterns were marked. To avoid the failure at applied load regions and to make sure that bearing stress was uniformly distributed at these loca- 
tions, a steel plate with dimensions of $(70,150$, and 20 $\mathrm{mm}$ ) soldered to a cylindrical shaft of (Ø $40 \mathrm{~mm}$ and along of $150 \mathrm{~mm}$ ) were utilized at load points. In addition to imitate the boundary conditions of the simply supported beam, the pin and the roller end supports have been used as per Al-Bayati [15] were used.

\section{Experimental results and discussion}

\subsection{Effect of web openings}

For solid deep beams most of the applied load is transmitted directly from loading point to the reaction point along the "load path". The cracking process in (D-1) started with the formation of flexural cracks at about $(160 \mathrm{kN})$ as shown in Table 16 , while the shear cracks appeared at about $200 \mathrm{kN}$ nearly in the mid-depth of the specimen in the direction of diagonal compression strut and thereafter expanded towards the load and the support points after the width of the diagonal cracks became more widening, this beam failed by shear mode with crushing of concrete near the loading point at a load of $760 \mathrm{kN}$. When load path was intercepted by the opening as in beam (DO-1) the cracking and ultimate load decrease by $50 \%$ as-compared with solid beam (D-1). The presence of openings raised the midspan deflection of the hollow deep beam when compared with solid beam (D-1) at the same load levels, such rise in deflection values was caused by decrease in moment of inertia as shown in fig.3.

\subsection{Effect of strengthening with CFRP}

\subsubsection{Cracking process and failure load}

The crack patterns of RC deep beams are shown in Plates (1). Generally, in strengthened beams after elastic stage the first shear crack, appeared in shear zone from the diagonal edges of the openings then expanded towards the load and the supports plates. With a further increment in the load, flexure cracks formed in the beams soffit as in control beam (DO-1). The first visible shear cracking and ultimate loads for all beams are summarized in the Table 16.The test results illustrated that the appearance of shear cracks were belated for the strengthened specimen somewhat more than reference beam and this may be refer to the increase of stiffness because the strips restraining effect. At the front face of beam, shear cracks appeared at load of $120 \mathrm{kN}$ for beams (DO-1-VH, DO-1-I) with increasing $20 \%$ in cracking load compared with reference beam (DO-1). While in beam (DO-1-V) shear crack formed at the same loading level for beam (DO-1). Table 16 also shows that beam (DO-1-A) has the highest ultimate load $(560 \mathrm{kN})$ among other strengthened beams in this group. The percentage of increase in ultimate load for this beam was about $47.4 \%$ as compared to the reference beam. This deep beam specimen was strengthened by covering the shear zone with vertical fibers. That reflects the advantage of CFRP strips in enhancing the ultimate strength of SCC deep beams, because they lead to delaying in the appearance of the shear cracks and gave good restraint to the next expansion of cracks. The failure type in this deep beam specimen was crushing of concrete along the line joining the edge of load points and opening tangents opposite to the load points under the CFRP which led to debonding the fiber and rupture it near the load point as shown in plate 1 . The strengthening system in beam (DO-1-V) was two vertical (U) shape CFRP strips on each side of this beam to investigate the influence of strengthening by using these strips on behavior of deep beam with openings. The Failure of this beam occurred by debonding of CFRP strip near the load point and rupture of CFRP strip near the support poin combined with splitting the specimen along the path connecting the bearing points and openings tangents opposite to load point at $(420 \mathrm{kN})$ as shown in plate 1 . The strengthening of (DO-1-V) results in about $10.5 \%$ increase in the ultimate load over control beam (DO-1). Beam (DO-1-I) was strengthened by two inclined CFRP strips (U) wrapped (orthogonal to the load path) mirrored on each side of the beam to discuss the influence of the fiber orientation on behavior of deep beams. The failure of this specimen was due to separation of the two strips from the concrete surface after diagonal crack became wider at ultimate load $(530 \mathrm{kN})$ as shown in Plate 1. Strengthening of this beam gave a $(39.5 \%)$ and $(26 \%)$ increase in the ultimate loads as compared to (DO-1) and (DO-1-V) respectively. As a concluding remark, the inclined orientation of strips in (DO-1-I) showed better performance than vertical placement in (DO-1-V) both with respect to first crack, ultimate strength of SCC deep beams as can be observed from Table 16. Beam (DO-1-VH) was constructed and tested to discuss the effect of adding horizontal CFRP strips to vertical CFRP strips when strengthening the deep beams. This beam was strengthened by two vertical CFRP strips (U) wrapped on each side and two horizontal CFRP strips on two faces of the beam. With increasing load, the shear crack extended towards the load and the support points and became wider under CFRP strips causing de-bonding of the vertical CFRP strip near load point and rupture of vertical CFRP strip near the support point and horizontal CFRP strips finally, the failure occurred at ultimate load $(500 \mathrm{kN})$ with $(31.5 \%)$ and $(19 \%)$ increase in the ultimate load as compared to the beam (DO-1) and (DO-1-V) respectively. 
Table 16. Test results of all beams

\begin{tabular}{|c|c|c|c|c|c|c|c|c|c|c|c|}
\hline \multirow{2}{*}{$\begin{array}{c}\text { Deep beam } \\
\text { No. }\end{array}$} & \multirow{2}{*}{$\mathbf{a} / \mathbf{d}$} & \multirow{2}{*}{$\begin{array}{l}\text { CFRP } \\
\text { details }\end{array}$} & \multicolumn{2}{|c|}{\begin{tabular}{|c|}
$\begin{array}{c}\text { Shear crack } \\
\text { force }\end{array}$ \\
\end{tabular}} & \multicolumn{2}{|c|}{$\begin{array}{c}\begin{array}{c}\text { Flexural } \\
\text { crack Force }\end{array} \\
\end{array}$} & \multicolumn{2}{|c|}{$\begin{array}{c}\text { Ultimate } \\
\text { Force }\end{array}$} & \multirow{2}{*}{$\begin{array}{l}\text { Increase } \\
\text { In } \\
\text { Ultimate } \\
\text { load \% }\end{array}$} & \multirow{2}{*}{$\begin{array}{c}\mathrm{Pcr}_{\mathrm{s}} / \\
\mathbf{P u}\end{array}$} & \multirow{2}{*}{$\begin{array}{l}\text { Mode of Fail- } \\
\text { ure }\end{array}$} \\
\hline & & & $\mathrm{Per}_{\mathrm{s}}$ & $\Delta \mathbf{c r} \mathbf{s}_{\mathrm{s}}$ & $\operatorname{Pcr}_{f}$ & $\Delta \mathbf{c r}_{\mathbf{f}}$ & $\mathbf{P u}$ & $\Delta \mathbf{u}$ & & & \\
\hline D-1 & 1 & - & 200 & 1.55 & 160 & 1.26 & 760 & 7.5 & - & 26.3 & $\mathrm{DS}+\mathrm{CC}$ \\
\hline DO-1 & 1 & - & 100 & 1.15 & 140 & 1.75 & 380 & 4.55 & - & 26.3 & DS \\
\hline DO-1-V & 1 & V & 100 & 1 & 220 & 2.32 & 420 & 4.65 & 10.5 & 23.8 & $\begin{array}{l}\text { FRPD } \\
+ \text { FRPT } \\
\end{array}$ \\
\hline DO-1-VH & 1 & $\mathrm{~V} \& \mathrm{H}$ & 120 & 1.07 & 180 & 1.66 & 500 & 4.8 & 31.6 & 24 & $\begin{array}{l}\text { FRPD } \\
+ \text { FRPT } \\
\end{array}$ \\
\hline DO-1-I & 1 & $\mathrm{I}$ & 120 & 0.98 & 240 & 2.06 & 530 & 4.7 & 39.5 & 22.6 & FRPD \\
\hline DO-1-A & 1 & A & - & - & 200 & 1.55 & 560 & 4.85 & 47.4 & - & $\begin{array}{c}\text { FRPD } \\
+ \text { FRPD+CC } \\
\end{array}$ \\
\hline
\end{tabular}

Where: V: vertical orientation, H: horizontal orientation, I: inclined orientation, Pcrs: the load at initiated first shear crack $(\mathrm{kN})$, Pcrf : the load at initiated first flexural $\operatorname{crack}(\mathrm{kN})$, Pu: failure load $(\mathrm{kN}), \Delta \mathrm{crs}$ : vertical deflection at initiated first shear crack, $\Delta$ crf: vertical deflection at initiated first flexural crack, $\Delta \mathrm{u}$ : vertical deflection at failure stage (mm), DS: diagonal splitting failure, FRPD: shear induced FRP Debonding, FRPT: FRP tearing.
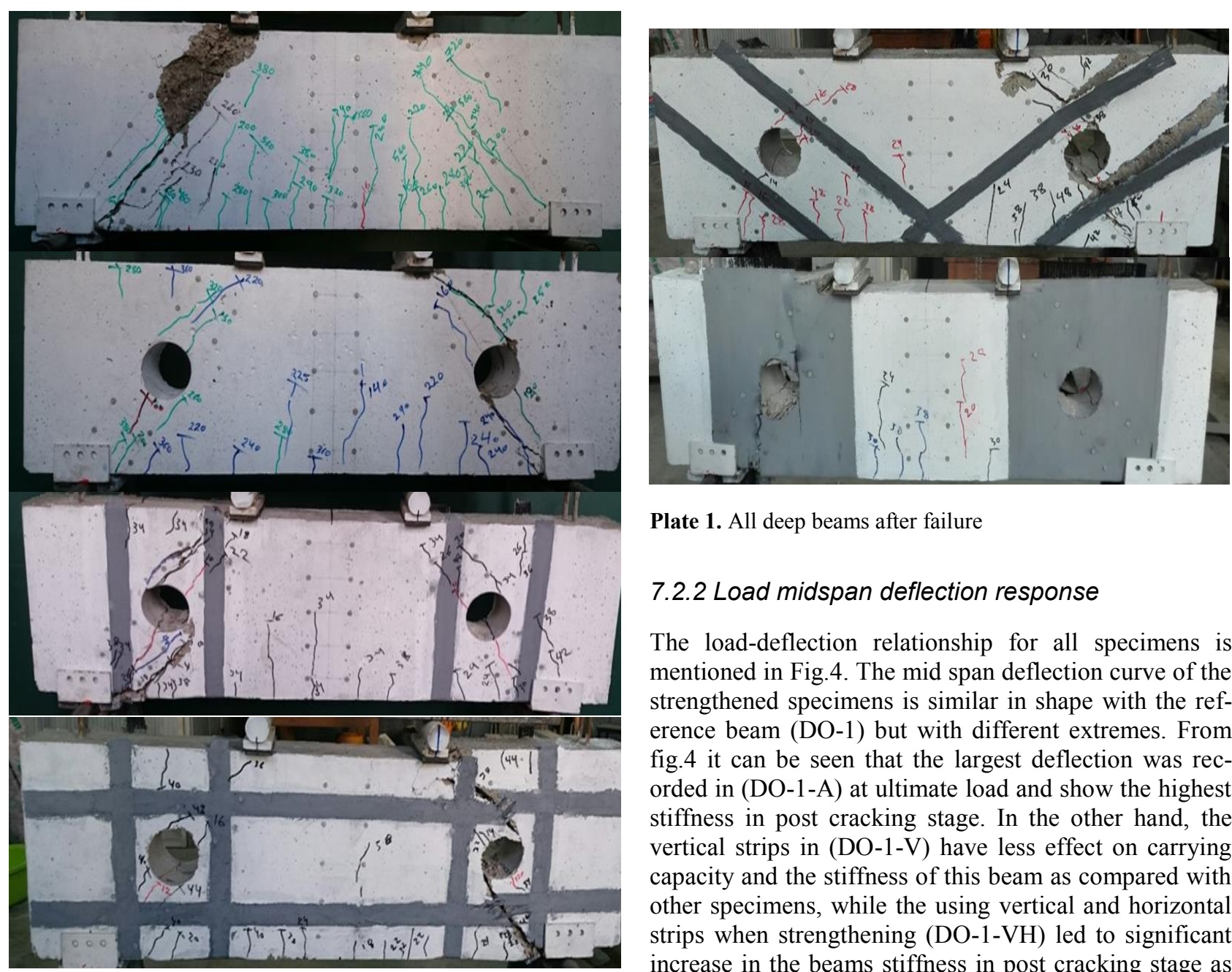

Plate 1. All deep beams after failure

\subsubsection{Load midspan deflection response}

The load-deflection relationship for all specimens is mentioned in Fig.4. The mid span deflection curve of the strengthened specimens is similar in shape with the reference beam (DO-1) but with different extremes. From fig.4 it can be seen that the largest deflection was recorded in (DO-1-A) at ultimate load and show the highest stiffness in post cracking stage. In the other hand, the vertical strips in (DO-1-V) have less effect on carrying capacity and the stiffness of this beam as compared with other specimens, while the using vertical and horizontal strips when strengthening (DO-1-VH) led to significant increase in the beams stiffness in post cracking stage as compared with (DO-1) and (DO-1-V). The deflection at ultimate load Of (DO-1-I) and (DO-1-V) are close to each other despite the difference in their ultimate loads 
(530 and $420 \mathrm{kN}$ ) respectively, this mean that the using inclined strips improve load carrying capacity and the

beams stiffness more than vertical strips.

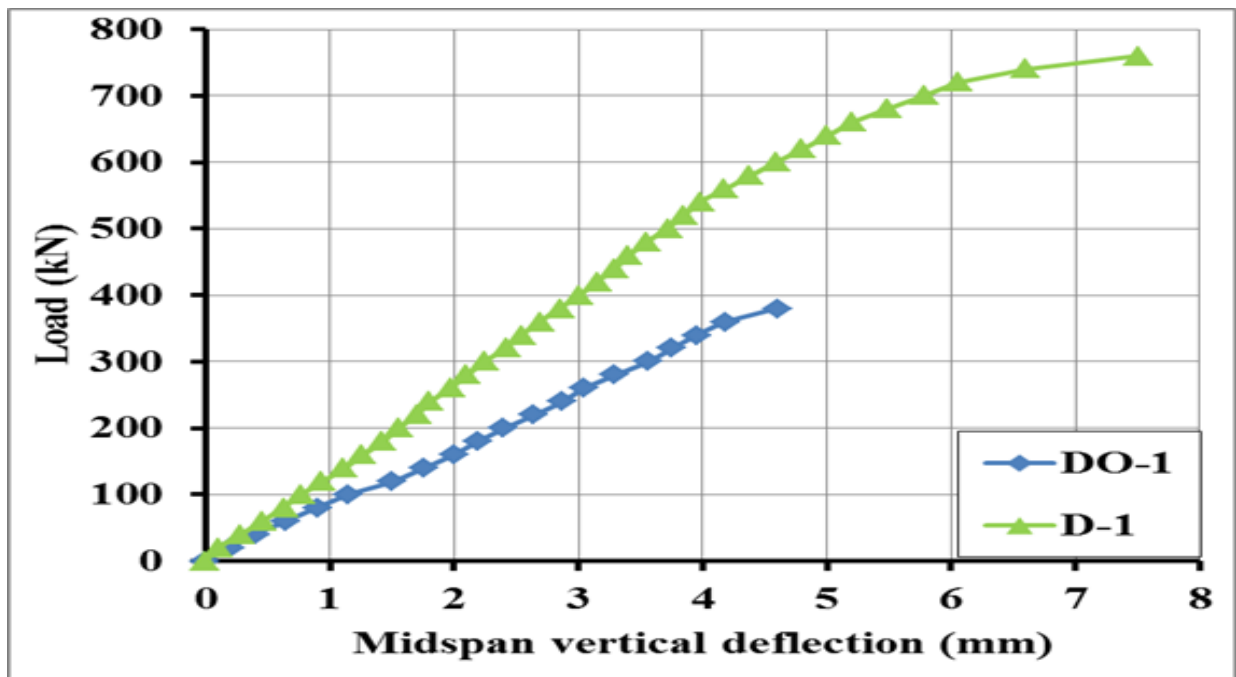

Fig 3. Relationship between load -deflection for deep beams with and without openings.

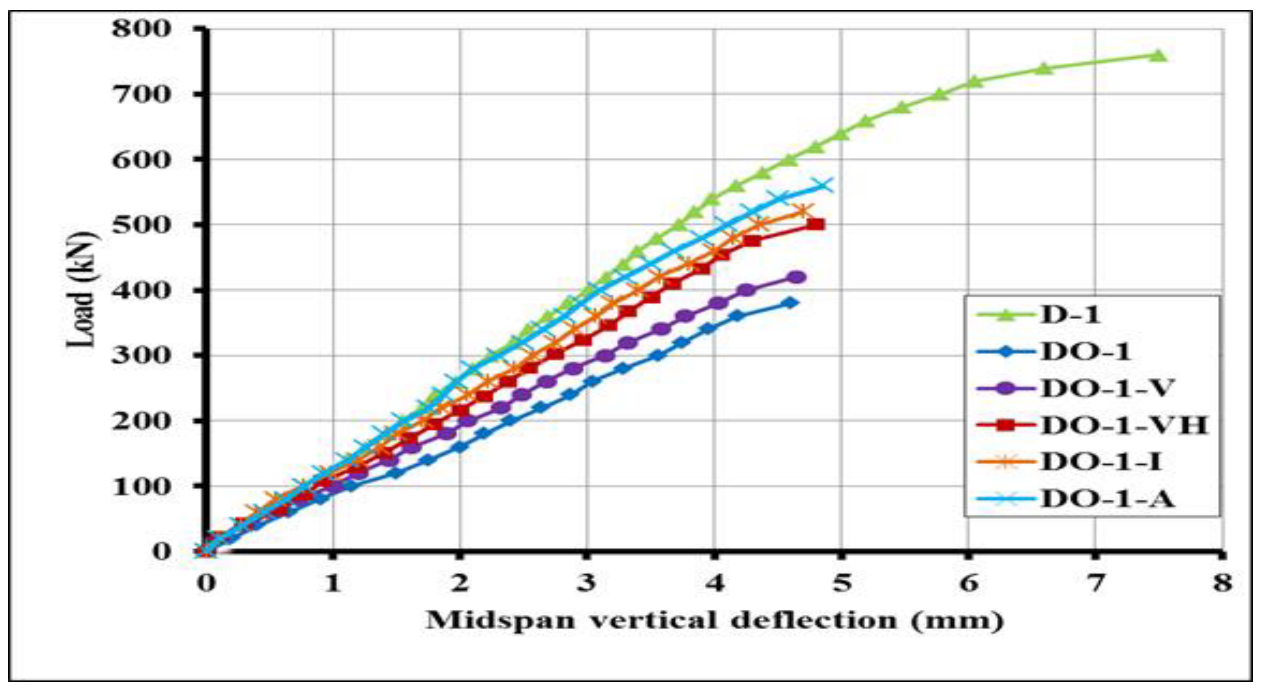

Fig4. Relationship between load-deflection for strengthening deep beams.

\section{Conclusions}

1. In this study, All deep beams failed in shear. This failure in the solid deep (D-1) was distinguished by a diagonal splitting type, which happened along path load between the load and support points. While, in deep beams with openings the failure occurred by splitting along the diagonal crack joining the load and support bearing edges with opening tangents opposite to them.

2. The presence of the circular openings in center of load path had a considerable influence on the load carring capacity of the concrete deep beams where a decreased in beam (DO-1) by about $50 \%$ as compared with corresponding solid one (D-1). While, the deflection increased in beam (DO-1) when compared with solid beam (D-1) at the same load levels.

3. Bonded CFRP system in the shear zone delayed the appearance of diagonal shear cracks slightly and gave good restraint to the next expansion of them. The shear crack load of the strengthened beams varies from (22.6 to $24 \%$ ) of their ultimate strength.

4. Generally, the strengthening self-compacting $\mathrm{RC}$ deep beam by CFRP strips reduces the deflection if compared at same loads levels and increases the load carrying capacity.

5. Using inclined strips of CFRP was more effective in upgrading the stiffness and shear strength of selfcompacting $\mathrm{RC}$ deep beams than the vertical one as could be seen in Table 16.

6. When combining CFRP strips in longitudinal direction of deep beam followed by vertical CFRP strips, the results showed that there was an additional increase ultimate load by $(19 \%)$ as compared with (DO-1-V).

7. Covering the shear span by vertical U-shape CFRP woven increased the ultimate load up to $47 \%$ and increases the stiffness. 


\section{References}

1. D.M. Rogowsky, and J.G. MacGregor, Structural Engineering Report, 110, Department of Civil Engineering, University of Alberta, Edmonton, 178 pp. (1983)

2. ACI Committee 237R, Reported by Emerg-ing Technology Series, 30 pp. (2007)

3. F. K. Kong, and G. R. Sharp, The Structural Engineer 51, 8, 267-275 (1973)

4. M. A. Mansur, and W. A. M. Alwist, The International journal of Cement Composites and Lightweight Concrete 6, 4, 263- 271 (1984)

5. A. F. Ashour, and Rishi, G., ACI Structural Journal 97, 3, 418-426 ( 2000)

6. K. H. Yang, H. C. Eun, and H. S. Chung, Engineering Structures Journal 28, 13, 1825-1834 ( 2006)

7. ACI Committee 318, "Building Code Requirements for Structural Concrete (ACI 318M-14) and Commentary," American Concrete Institute, Farmington Hills, MI 48331, USA, 520 pp. (2014)

8. IQS No. 5/1984 "Portland Cement" Central Agency for stand-ardization and Quality Control, Planning Council, Baghdad, IRAQ, (in Arabic)

9. ASTM C 33-03, "Standard Specification for Concrete Aggregate Annual Book of ASTM Standards, Vol.04.02 Concrete and Aggregates, West Conshohocken, PA, United States, , pp. 11, (2003)

10. IQS No. 45/1984, Aggregate from Natural Sources for concrete" Central Agency for standardization and Quality Control, Planning Council, Baghdad, IRAQ,(in Arabic)

11. ASTM A615/A615M-14, "Standard Specification for Deformed and Plain Carbon-Steel Bars for Concrete Reinforcement," ASTM International, West Conshohocken", PA, 7 pp (2014)

12. ASTM A1064/A1064M-14, "Standard Specification for Carbon-Steel Wire and Welded Wire Reinforcement, Plain and Deformed for Concrete," ASTM International, West Conshohocken", PA, 11 pp. (2014)

13. Bibm, CEMBUREAU, EFCA, EFNARC, ERMCO, "The European Guidelines for Self-Compacting Concrete," http://www.efnarc.org. (2005)

14. EFNARC: European Federation Dedicated to Specialist Construction Chemicals and Concrete Systems, Association House, 99 West Street, Farnham, Surrey, U.K, 32 pp. (2002)

15. N. A. J. Al-Bayati, Ph. D. Thesis, Building and Construction Engineering Department, University of Technology, Baghdad, Iraq, 298 pp. (2012) 